\title{
Examining the Sustainable Urban Environments
}

\author{
By Berna Dikçınar Sel ${ }^{1}$, Banu Çelebioğlu ${ }^{1}$, Olcay Çetiner Özdemir ${ }^{1}$
}

\begin{abstract}
Cultural properties, as they narrate the design, art and architectural mentality of the entire periods that they went through from the date they were built until today, are museum-quality buildings that document the social and cultural status. The "Harran Houses" in the Harran city are among this cultural wealth. The typical conic domed houses date back to 150-200 years from today that are in Harran city which was registered as an archaeological and urban conservation area in 1979 and safeguarded. Within the scope of sustainability of these kinds of settlements to be transferred to the future generations; the importance of achievement of the effective contribution of the ruling authorities, users, local residents and visitors to the recommendations that set forth during the study, importance of development and keeping them alive can be understood. In the study, the touristic purposed usage is recommended for the Harran houses; evaluating the current structural status and environmental requirements of the houses through the data obtained during the "Harran2014" workshop. Evaluation of sustainability of the cultural heritage in architecture from a tourism point of view by discussing sustainability is being transferred together with the distinctive characteristics and the design approaches of the functions.
\end{abstract}

Keywords: Sustainability, Historical City Centers, Architectural structures

\section{Introduction}

There are places that are left to decay and buildings to be protected in many cities. As a result of the movements in tourism that have become a need, people begin to see and experience the city textures that are the products of different cultures and consequently, reviving old city areas becomes a must.

Tourism should be evaluated as a sustainable progress tool to obtain the continuity in the areas which acquires cultural heritage and natural values. It is observed that, the two important visual features in tourism are the environmental characteristics and the architectural characteristics of the accommodation buildings that belong to cultural heritage.

Turkey is of which the historical heritage mostly continues its presence lively with its natural and cultural values, it is certain that there is a significant potential in several regions of our country in terms of sustainable tourism. (Tosun, Ç. and Şahin, S.Z., 2006). Sustainablity should be developed without giving any harm to the environment; society; historical, natural and cultural assets so as to contribute to the regional economy and social life.

\section{A General Overview of the Harran and of the Historical Structure}

Harran is located $44 \mathrm{~km}$ southeast of Sanliurfa which is one of the most important cities of Southeast's region of Turkey. City of Harran was founded in the center of the Harran Plain which was named same with the city. Harran Plain has an area of 160,000 hectares.

It is understood from historical documents and archaeological excavations that the name of Harran have remained unchanged for 4000 years. 
Harran is located on the crossroad of the important trade routes that are coming from northern Mesopotamia and connecting to the west and north-west. Due to this feature, Harran had been one of the most popular places of traders of Assur who had tight trade relations with Anatolia. The trade from Anatolia to Mesopotamia and from Mesopotamia to Anatolia had been through Harran for thousands of years. Hence, this has led to the formation of a rich and deep-rooted cultural background here. In the period that Urfa was one of the most important centers of Christianity, Harran was named "Hellenopolis" which means the City of Pagans. In 1260, the Harran Mosque, its walls and its castle were destroyed. After that, Harran could not return to its old glorious days, even during the Ottoman period (1).

Harran had been founded in northern Mesopotamia, on a plain watered by two rivers and at that time Harran Plain was an agricultural area with a network of irrigation channels. Those channels have been destroyed due to prolonged drought.

It is known that there were 4 universities, one hospital and 8 baths in Harran by the 13th century. Today, Harran gives an existence battle against time with its archaeological history and largely ruined dome houses.

Şanliurfa and Harran were the settlements with the emigration to the west of the country as the other cities in the region until the beginning of 1990. One of the most important stages of the Southeastern Anatolia Project ${ }^{1}$ was the watering the Harran plain. In this regard, an area of 58.000 hectares in the plain has been available for irrigated agriculture since 1992. And, by 1999, the irrigated area reached to 137.362 hectares. Thus, Şanliurfa and Harran have become settlements allowing immigrants into not migrated from (1).

Harran's urban population increased by 135,41 per thousand from 1990 to 2000 with a rapid migration. While Harran's population was 27.325 in 1990 , the number has reached to 78.681 according to data by 2014.

On the basis of Harran's dome houses which have original architecture and urban texture formed by those houses the Ashiret Culture or Ashiret organization is located. The form of tribal organizations in the region and in Şanlıurfa is called Ashiret. The lineage units forming the Ashiret in the social organization hierarchy of nomadism are called "tribe". In its short form "Ashiret" is the upper union consisting of tribes with the same ancestors or having a lineage link between them. Nomadic or resident tribes still exist in the related region. Yet, it is well known fact that the resident tribes were also nomadic in the previous period (1).

Harran's dome houses are the spatial reflections of the nomadic and Ashiret culture. On the basis of the aforementioned culture are to produce the most practical solutions by benefiting maximum from the natural resources of the geography such as materials, climate and topography and to live in harmony with nature. Harran's dome houses are the most important spatial reflections of this culture. Houses are increased in a modular manner and shaped according to needs. Houses are located in the orientation so as their yards to be protected from sun at longest time. The same concerns in terms of the houses, plots and street relationship were pursued and although the slope is not very high, an organic street pattern has been established. Little shades, even when the sun is the highest, are created due to the narrow and serpentine street tissue.

The phenomenon embodied as a unique housing and city scheme in Harran is culture. As well as the spatial elements of each city provide clues on the social and cultural life in the city, the reflection of that culture is also the city itself. The richness of spatial elements is the expression of rich social and cultural life of the city. All these are the elements that make up the identity of that city. Urban identity is a whole composed of factors which belong to the city, make it different from the others and add value to that urban and are urban-specific (2).

1 The Southeastern Anatolia Project is a regional development project involving dam projects to irrigate the agricultural land and to obtain energy in Turkey began in the 1960s and ended in the 2000s. 
Today's Harran is experiencing the process of losing its original identity with the impact of rapid migration and changed living conditions. In the plain, the "New" Harran city is continuing its development with the reinforced concrete housings which can be built by any construction foreman in any city in the country, and none of which has motifs peculiar to the area, at the north of the Harran city which consists of the valuable cultural heritage. Beside this the "Old" Harran although it is in the scope of protection of cultural heritage is being destroyed rapidly and it is experiencing a process that housings are built like in "New" Harran.

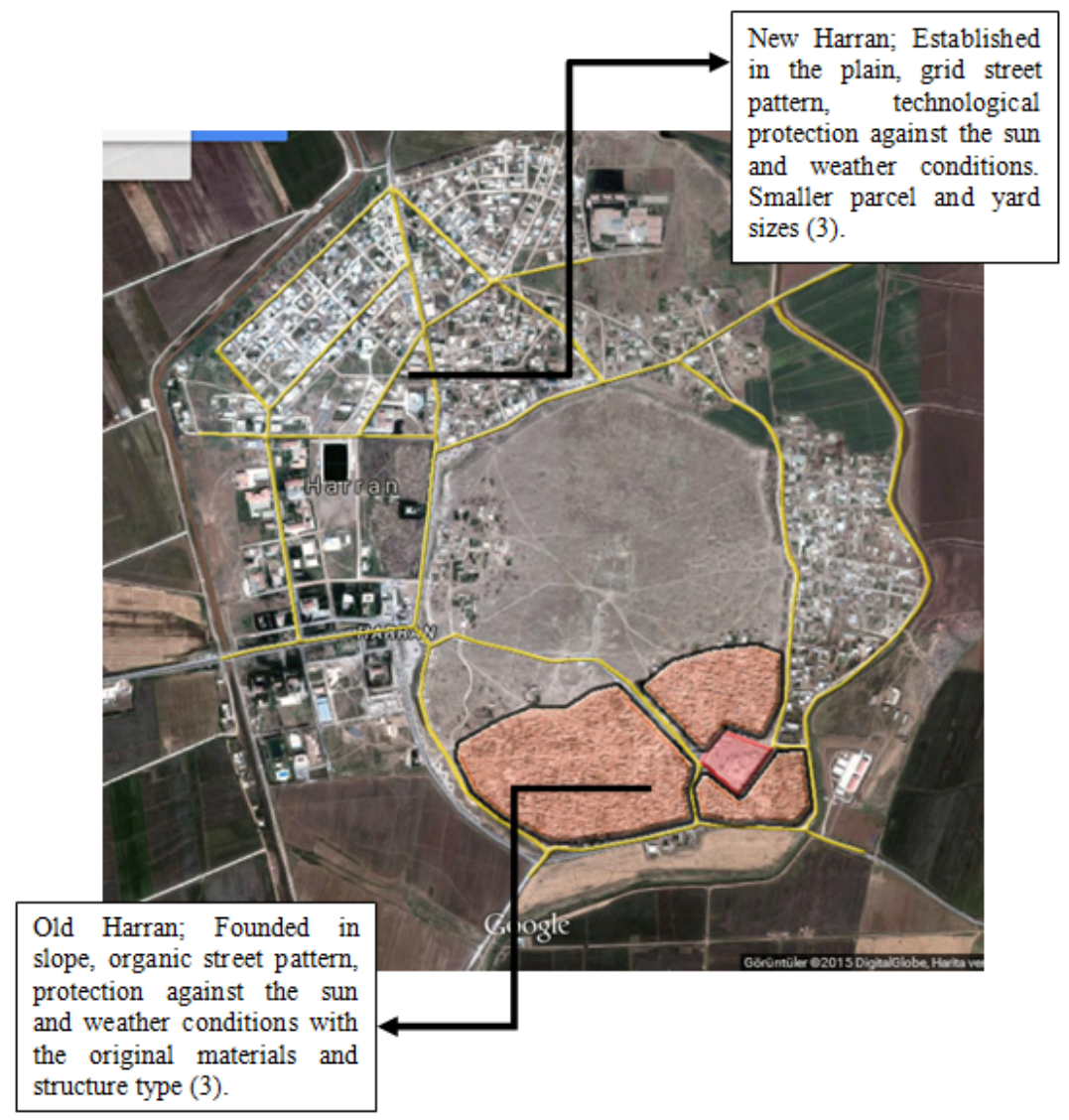

Figure 1 Harran (Harran 2014 Workshop, 2014)

\section{Vernacular Architecture of Harran and Architectural Features}

\subsection{Vernacular Architecture of Harran}

The vernacular architecture of Harran is characterized by the different combinations of the domed units (Photo 1.1). The houses are built over the past 150-200 years, on the ancient city ruins. The shape of the dwellings is influenced on the way of life of the earliest inhabitants, the Syrians who were immigrated in this region. They constructed their houses like tents with aspect of nomadic life. 


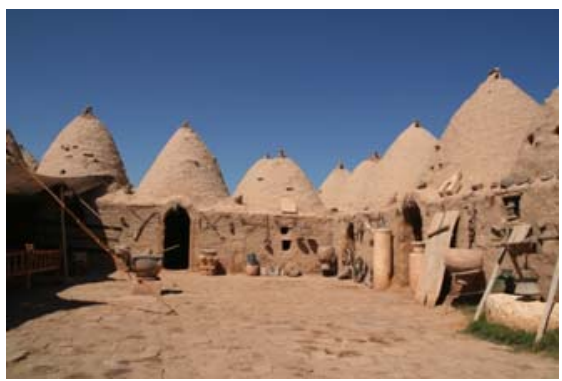

Photo 2.1 Traditional Harran house (Celebioglu, 2014)

Since the 1950s, the construction of the reinforced concrete buildings has increased rapidly for reasons such as lack of compability with modern living conditions of existing structures, migration and convenience in transport ${ }^{2}$. The view of the cultural landscape created by the lowland, domed houses, castle, Great Mosque which built on the ruins of the University of the Abbasid era and ancient settlement, began to disappear (Photo 1.2). The settlement has been declared as an urban and archaeological site in 1979, but it didn't prevent the degradation of the cultural heritage.
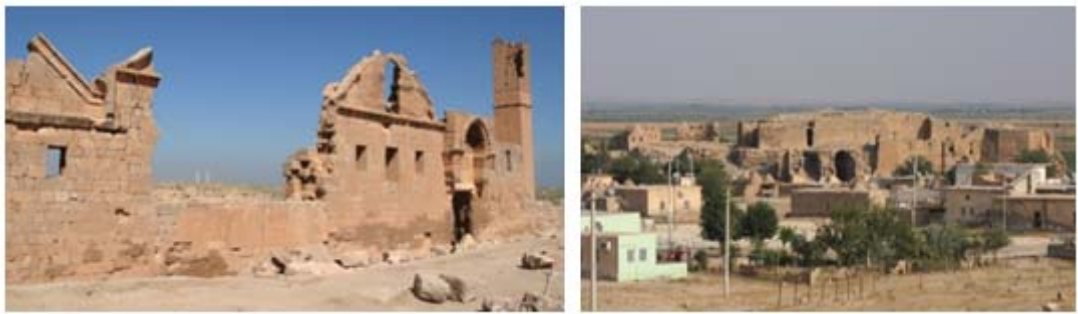

Photo 2.2 Harran Great Mosque and Castle (Celebioglu, 2014)

Harran has different conservation problems due to various reasons in terms of traditional architecture. Particularly, the buildings are abandoned and fall into ruin due to the lack of maintenance because of losing the housing function. Today, most of the buildings has converted to the barn and hayloft. The domes of the abandoned houses are collapsed in time and they gain a tumulus appearance (Photo 1.3).

Photo 2.3 Abandoned houses (Cel., 2014)

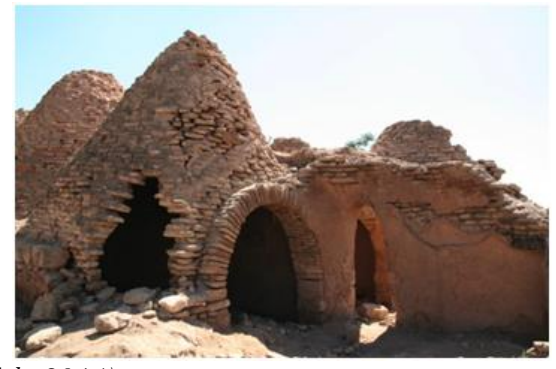

2 Akın, G. Akın, N. Eres, Z. İvedi, B. "Şanlunfa, Birecik-Suruc Kırsal Mimarllk Envanter Raporu”, Turkish Academy of Sciences TÜBA-TÜKSEK, Ankara, 2002, p.119-192. 


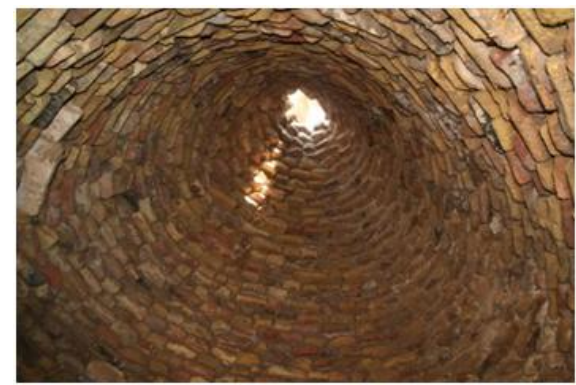

Photo 2.4 The dome opening (Cel., 2014)

\subsection{Architectural Features}

Traditional Harran houses have a square plan and they are covered by a dome constructed with overlaid bricks in narrowing cone shape. Transition to the dome from the walls is provided with a simple pendentive.

The interior height of the domed unit is approximately $5 \mathrm{~m}$. Domes are built with 30-40 series of brick. The only light source for the houses, is the small opening on the cone's top (Photo 1.4). This opening is used also for smoke evacuation.

Connection between the domed units is usually provided with one meter openings in the corner or in the middle of the wall. The plan typology of domed units is variable, it can be changed due to the number of users and economic circumstances.

The walls constructed with alternating courses of stone and brick, are coated with mud plaster. The inner surface of the dome has been left unflustered. The brick overhangs are placed at the exterior surface of the dome with regular intervals. These overhanging are used for the repair of the dome and for closing partially or completely the hole at the top, in rain and cold weather (Photo 1.5).
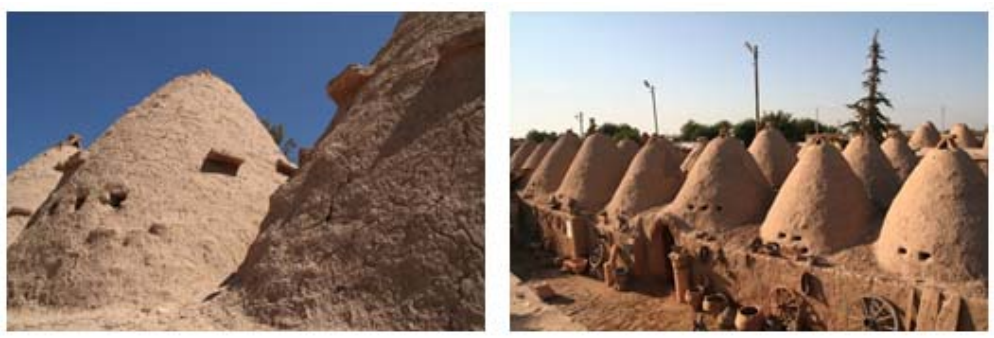

Photo 2.5 Domes of Harran houses (Celebioglu, 2014)

\section{Sustainable, Historical Urban, Tourism: Harran}

Sustainability is a world view which aims to provide the economical, environmental and societal requirements without harming the future generations' conditions of life. Sustainable architecture is a holistic process that aims to provide and sustain the consistency in-between natural and structured environment while comprising settlements that suit dignity of man.

The cultural values, that are brought from past until today, to the next generations and enabling the reutilization of present resources bring cultural, economic and social benefits to the society (Eyüce, 2005). Conventional housings, which are the important historical, cultural and structural heritages of societies, undergo a change for various reasons during long-term usage. Conventional housings might become unresponsive to up-to-date needs and requirements of users that emerge 
in association with changes in the social life. The physical arrangements, which will enable the conventional housings to respond to up-to-date needs and requirements that develop in association with the cultural and vital change, should be performed in an interaction with the original structure and material (Perker, Akıncitürk, 2011). It becomes possible for conventional housings that have lost their original function to be adapted into modern usages and reused. The new functions of structures are determined for the intense usage, but also the conventional housings are kept alive (Haştemoğlu and Sezgin).

During the restoration works, the environmental integration, spatial features and schemes of the structure should be protected (Tapan, 2007). Incompatibility of the materials being used on the structure is one of the most important factors accelerating the corrosion process. Therefore, attention must be paid to select the new material that will be involved in the structure, in such a way to protect the original material and comply with it (1). It is important to implement the techniques accurately, select the accurate materials during restorations and repairments and be faithful to the original in building techniques. During the implementations, the methods and materials to be used should comply with the structure. Otherwise, the structure might moulder and even collapse in advanced stages.
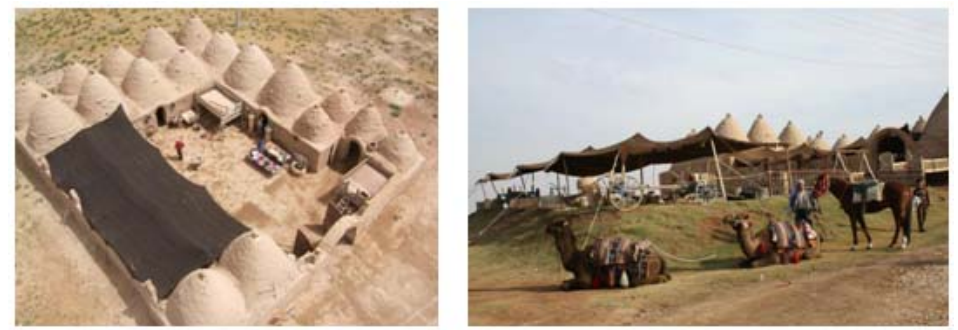

Photo 3.1 Views of Harran houses

Harran Houses that are in historical centers should have facades with properties that will attract attention. In order to establish a traditional place that reflects the regional life style, the first thing to do should be examining the regional architectural style and combining these properties with the interior and exterior design (Photo 3.1).

Architecture and interior design should be in compliance with the natural environment and connected to the main properties of the environment. The most important reason of why a guest prefers a specific place for holiday is the natural view and surroundings. This preference depends on transferring interior design components into this atmosphere. The materials to be used in interior and exterior designs should be determined. Accommodation facilities can be designed with one floor that compose of entrance, reception, kitchen, dining room and bedrooms. For room design; room measurement, room layout, room groups that include the number and type of rooms, recommended furniture and lighting, objectives of the sector, etc. should be taken into account.

Rooms of the accommodation facilities that are examined in the study have been observed in three different categories (Table 1). 
Table 1. Spaces that lead the design for Accommodation places that are examined in this study (Özdemir,2014)

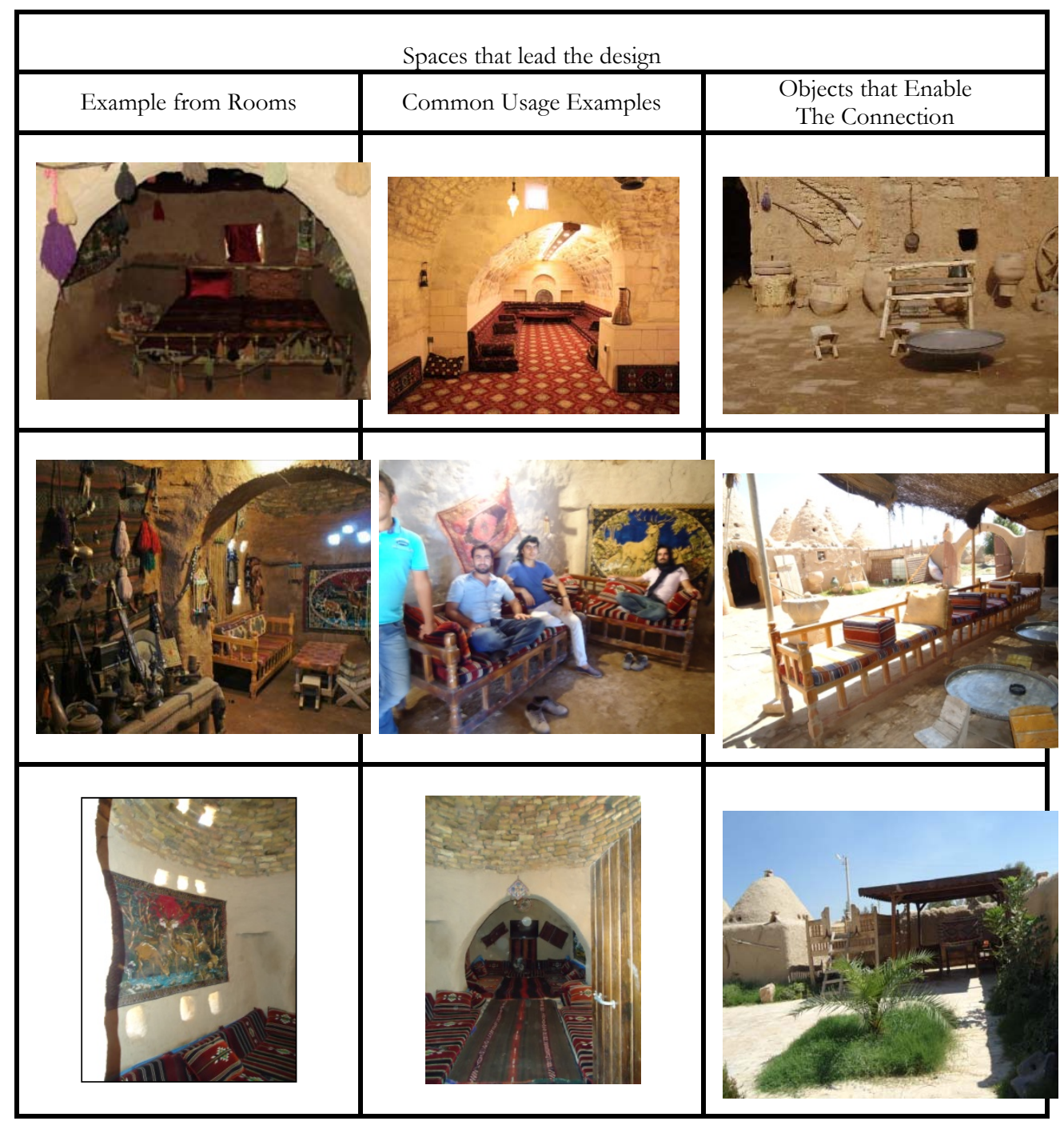

Only basic design/furniture has been selected for the room furnishing. Special attention paid for the optimum use of regional furniture according to the requirements. The purpose was to make the room look bigger and create well-used interior spaces. Spaces gave been decorated with traditional objects and motifs. It is a fact that design criteria that include all the plans and designs, which aim to ensure sustainability while using or creating environment, will shape tourism architecture. Because success, future and sustainability in tourism will be achieved with the help of structuring and design that reflect the importance given to environmental values. 


\section{Conclusion}

Architectural character should definitely be protected and the innovations to be made should emphasize the character. It should be remembered that a careful and authentic innovation would provide urban and architectural richness. The new functions to be brought during renovation should be made by considering the cultural value, spatial requirement and aesthetical preference and livable space should be created. Therefore, tourism can be sustainable by protecting the natural environment, historical heritage and cultural texture.

The historical urban areas which stand as a bridge between the past and the future and enable their sustainability. Keeping the historical urban areas alive is important for the sustainability of connection with the past, in terms of architecture. Therefore, tourism can be sustainable by protecting the natural environment, historical heritage and cultural texture.

"Understanding the space is not about understanding only the topography. We should pay attention to its smell, resonance and memories as well. It is not a relation that is determined unilaterally...

The relation of architecture and "space" is a reciprocal transformation, "detection-poiesis" relation. The space presents a ground for architecture to root and the architecture, in return, makes the good qualities of space visible. If this relation becomes a unilateral construction process, the "spirit of the space-genius loci" cannot get along together anymore." Tadao Ando

\section{References}

Şanlıurfa Il Geliş̧me Planı Çalışmaları, derleyenler; Melih Ersoy,H. Tarık Şengül, Rapor, Ankara, 2003.

Harvey, david (2002) Toplumsal Adalet, Postmodernizm ve Kent, 20. Yüzyll Kenti, der. ve Çev. Duru, B ve Alkan, A. Imge Kitabevi.

Harran 2014 Workshop, 2014, Urfa.

Akın, G. Akın, N. Eres, Z. İvedi, B. "Şanlunfa, Birecik-Suruc Kırsal Mimarllk Envanter Raporu”, Turkish Academy of Sciences TÜBA-TÜKSEK, Ankara, 2002, p.119-192.

Celebioglu B., Photos, Harran 2014 Workshop, Urfa, 2014.

Çetiner, O., Gökyllmaz Ç., A., 2006, Balıkesir - Ayvalık İlçesi Turizmde Tanıtma ve Pazarlamada Yeni Yaklaşım - Konaklama Mekânlarında Tasarım Etkileri -, II. Balıkesir Ulusal Turizm Kongresi Balıkesir Üni. Turizm İşl. ve Otelcilik Y.O., Balıkesir.

Çetiner, O., Gökyılmaz Ç., A., 2006, Antalya Turizmi Konaklama Mekanlarnn Kullanımında Tasarm Etkilerine Öneri, Turizm ve Mimarlık Sempozyumu-Turizmde Sosyal, Kültürel, Fiziksel Gelişmeler: Sorunlar ve Öneriler, Antalya.

Negrusa, A. Ve Ionescu, C.E., Design Implications in Creating A Competitive Advantege for Hospitality Small Business, Studia Universitatias Babes-Bolyai Negotia, No.1/2005, Syf.102-112, ISSN 1224-8738.ClujNapoca, Romanya.

-Özdemir Ç.O., Photos from Harran 2014 Workshop, Urfa, 2014.

Çetiner, O. and A. Ç. Gökyilmaz, 2011, "Evaluation of the Sustainability on Cultural Heritage and Environmental Factors in Architecture from a Tourism Point of View: Ayvalik Historical City Center", Part II, Cultural Heritage and Environmental Factors, Survival and Sustainability: Environmental Concerns in the 21 st Century, ed: Gökçekus, H., Turker U., LaMoreaux, J. W., ISBN : 978-3-540-95990-8, Springer, Berlin. pp:179-186

Çetiner Özdemir, O, Gökyılmaz A., Gökyılmaz B., (Ekim, 2012) "An application directed at using authentic materials when renovating historic structures", The 8th International Conference SAHC 2012 (Structural Analysis of Historical Constructions), Poland. 